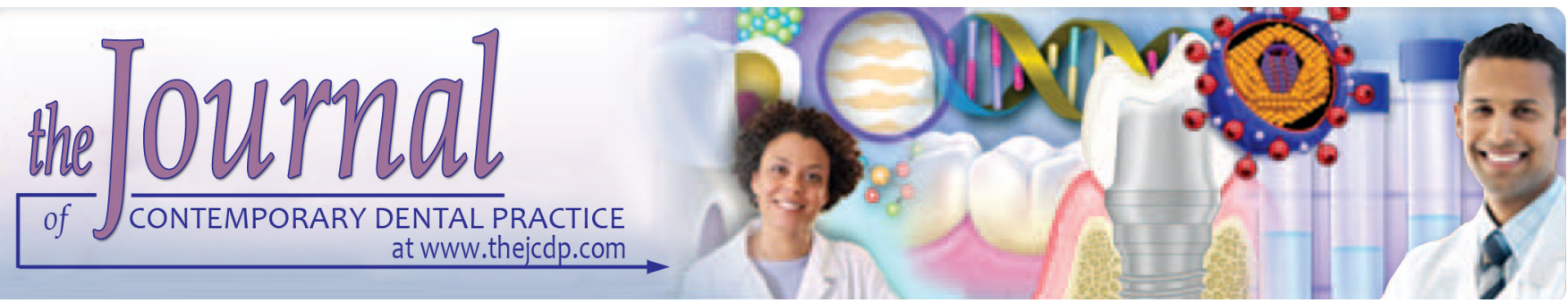

\title{
An In Vitro Comparative Evaluation of Antimicrobial Efficacy of Propolis, Morinda Citrifolia Juice, Sodium Hypochlorite and Chlorhexidine on Enterococcus faecalis and Candida albicans
}

${ }^{1}$ Monika Singh, ${ }^{2}$ Shikha Singh, ${ }^{3}$ Abdul R Salgar, ${ }^{4}$ Nandagiri Prathibha, ${ }^{5}$ Namratha Chandrahari, ${ }^{6}$ Lingam A Swapna

\begin{abstract}
Aim: To evaluate the antimicrobial effectiveness of Propolis, Morinda citrifolia juice, Sodium hypochlorite and Chlorhexidine on Enterococcus feacalis (E. feacalis) and Candida albicans (C. albicans), as endodontic irrigants.
\end{abstract}

Materials and methods: Four clinical isolates and one standard ATCC sample (29212) of E. feacalis and ATCC sample (90028) of C. albicans were inoculated into $5 \mathrm{ml}$ of peptone water each and incubated at $37^{\circ} \mathrm{C}$ for 3 to 4 hours to attain the turbidity corresponding to $0.5 \mathrm{McF}$ arland standard CFU. We followed Disc and well diffusion Kirby-Bauer method to attain the zones of inhibition.

Results: Overall comparison of reagents revealed a significant difference among zones of inhibition. The standard concentration of $5 \%$ sodium hypochlorite, $2 \%$ chlorhexidine, $10 \%$ Propolis and $100 \%$ Morinda citrifolia juice illustrated the maximum inhibition zone for both test organisms.

Conclusion: All four reagents had an antimicrobial effect on the microorganisms tested. Sodium hypochlorite and Chlorhexidine were more effectual than Propolis and Morinda citrifolia juice

${ }^{1}$ Department of Conservative Dentistry and Endodontics, Modern Dental College and Research Center, Indore, Madhya Pradesh, India

${ }^{2}$ Department of Conservative Dentistry and Endodontics, Peoples Dental College and Research Center, Bhopal, Madhya Pradesh, India

${ }^{3}$ Department of Prosthodontics Crown and Bridge, Al Badar Dental College and Research Center, Gulbarga, Karnataka, India

${ }^{4,5}$ Department of Prosthodontics Crown and Bridge, Government Dental College, Hyderabad, Telangana, India

${ }^{6}$ Department of Surgical and Diagnostics Sciences, Dar Al Uloom University, Riyadh, Kingdom of Saudi Arabia

Corresponding Author: Monika Singh, Department of Conservative Dentistry and Endodontics, Modern Dental College and Research Center, Indore, Madhya Pradesh, India e-mail: drmonikasingh4@gmail.com and there was increased antimicrobial efficacy with increasing concentrations.

Clinical significance: A study for finding safe herbal agents that can be used as endodontic irrigants revealed that Propolis, Morinda citrifolia juice has antibiotic properties and can replace routinely used agents thereby limiting the side effects.

Keywords: Candida albicans, Chlorhexidine, Enterococcus feacalis, Morinda citrifolia juice, Propolis, Sodium hypochlorite.

How to cite this article: Singh $M$, Singh $S$, Salgar AR, Prathibha N, Chandrahari N, Swapna LA. An In Vitro Comparative Evaluation of Antimicrobial Efficacy of Propolis, Morinda Citrifolia Juice, Sodium Hypochlorite and Chlorhexidine on Enterococcus faecalis and Candida albicans. J Contemp Dent Pract 2019;20(1):40-45.

Source of support: Nil

Conflict of interest: None

\section{INTRODUCTION}

Endodontic failures are mainly ascribed to the existence of microorganisms in root canals. ${ }^{1}$ Removal of microorganisms along with debris is a vital aspect for a good root canal therapy (RCT) outcome. Many microbial organisms like E. faecalis, C. albicans were found in endodontic infections with studies showing that both these microbes lead to RCT failure. ${ }^{2,3}$

E. faecalis, a gram-positive organism, even though present in minute quantity has a key role in causing continual periradicular infections and root canal failures, by genetic polymorphism and dentin binding property. Studies reported E. faecalis in 4 to $40 \%$ of root canal infections and increased incidence of about nine times in treatment failures. ${ }^{4}$ C. albicans is an opportunistic dentinophillic yeast showing an increased incidence in infected canals and peri-radicular tissues. ${ }^{5}$ 
Successful RCT aims at total elimination of infected tissue by disrupting and removing all the microbes, which requires profuse, repeated irrigation with intracanal medicaments apart from mechanical debridement. Irrigants frequently used in RCT are sodium hypochlorite $(0.5-5.25 \%)$, hydrogen peroxide $(3 \%)$ solution, EDTA, chlorhexidine gluconate $(0.2-2 \%)$ and physiologic saline solution. ${ }^{1-3}$

Sodium hypochlorite is most frequently used medicament and has an antimicrobial effect and is a good organic tissue solvent, without leaving any noxious residues. It has few drawbacks like bad taste, toxic in nature, instrument corrosion, inflammatory and allergic reactions. ${ }^{1,6}$

Two percent chlorhexidine gluconate as intracanal irrigant has broad antimicrobial activity. It is less toxic, with disadvantages of discoloration of teeth, bad taste, dry mouth and in general inferior than hypo in antimicrobial removal. ${ }^{1,7}$

Hence research was done to look for safer herbal agents. A literature search showed that few agents have antimicrobial properties like Propolis, Morinda citrifolia juice and whether they may be employed as endodontic irrigants. ${ }^{2,3}$

We carried this study to appraise the antimicrobial effectiveness of propolis, sodium hypochlorite, morinda citrifolia juice and chlorhexidine on E. feacalis and C. albicans, as endodontic irrigants.

\section{MATERIALS AND METHODS}

Four clinical isolates and one standard ATCC sample (29212) of E. feacalis and ATCC sample (90028) of C. albicans were inoculated into $5 \mathrm{~mL}$ of peptone water each and incubated at $37^{\circ} \mathrm{C}$ for 3 to 4 hours to attain the turbidity corresponding to $0.5 \mathrm{McF}$ arland standard CFU. We followed disc and well diffusion Kirby-Bauer method to attain the zones of inhibition.

Plates for Muller Hinton agar (MHA) at a ph of 7.2-7.4 with a depth of $4 \mathrm{~mm}$ were prepared for E. Faecalis and similarly for Candida albicans plates with Muller Hinton agar $+2 \%$ glucose, and $0.5 \mu \mathrm{g} / \mathrm{mL}$ methylene blue dye was prepared. A $50 \mu \mathrm{ml}$ of the microbial suspension was kept on an agar plate and was further evenly spread with L-spreader.

\section{Preparation of Irrigants}

Ten percent Propolis solution was made by dissolving $500 \mathrm{mg}$ tablet in $5 \mathrm{~mL}$ of warm sterile distilled water and likewise, a range of concentrations was obtained, i.e., $2.5 \%$ and $5 \%$.

Three percent, $1.5 \%$ and $0.75 \%$ morinda citrifolia juice were made by diluting $100 \%$ juice.
Three percent, $2.5 \%$ and $0.5 \%$ sodium hypochlorite was made by diluting $5 \%$ hypo.

One percent, $0.5 \%$ and $0.22 \%$ chlorhexidine was made from $2 \%$ solution.

\section{Disc Preparation}

Disc preparation was done by impregnating the disc with dissimilar concentrations of irrigants. Using sterile forceps antimicrobial impregnated disc was kept on the agar surface with minimum $20 \mathrm{~mm}$ distance between each disc. An anti-bacterial sensitivity disc of chlortetracycline and Voriconazole which are considered as the control group was placed in the center of the plates containing E. faecalis and C. albicans respectively. The plates were inverted and incubated at $37^{\circ} \mathrm{C}$ for $16-18$ hours for E. faecalis and $24-48$ hours for C. albicans.

\section{Preparation of Wells}

With a sterile cork borer, evenly distributed holes were made and samples were loaded in each hole. The plates were incubated at $37^{\circ} \mathrm{C}$ for 16 to 18 hours and 24 to 48 hours for E. faecalis and C. albicans, respectively.

The presence and size of the inhibitory zone for each antimicrobial agent were measured on the plates by Hi-media scale. Observations were made with unaided eye while viewing the back of the Petri dish with reflected light against a black non-reflecting background. The measurement of zones of inhibition was done at a standard concentration of various antimicrobial agents followed by zones at different concentrations.

Medians and quartiles were represented for comparing the zones of inhibition for the four standard agents across the various clinical isolates of the microorganism. The relationship between the increasing concentration of an agent and its influence on zones of inhibition was tested using Spearman's correlation coefficient. The comparisons between four standard concentrations were analyzed by the Kruskal-Wallis test. The comparison of individual standard agents was further analyzed using Mann--Whitney test, with considering p-value of $<0.05$ as statistically significant.

\section{RESULTS}

Comparison of reagents against E. faecalis revealed a significant variation among zones of inhibition (Table 1 and Graph 1-Box plot). Among individual groups, there was the insignificant difference between $10 \%$ propolis and $100 \%$ morinda citrifolia juice and between $2 \%$ chlorhexidine and 5\% hypo. Both herbal agents had significantly lesser inhibition compared to $2 \%$ chlorhexidine and $5 \%$ hypo. 
Table 1: Zones of inhibition for $E$. faecalis in millimetres comparing the four standard concentration of test agents

\begin{tabular}{|c|c|c|c|c|}
\hline $\begin{array}{l}\text { Agent and } \\
\text { the standard } \\
\text { concentrations }\end{array}$ & $\begin{array}{l}\text { Median } \\
\text { zones of } \\
\text { inhibition for } \\
\text { E. Faecalis }\end{array}$ & $\begin{array}{l}\text { First } \\
\text { quartile }\end{array}$ & $\begin{array}{l}\text { Third } \\
\text { quartile }\end{array}$ & $\begin{array}{l}\text { p-value } \\
\text { (Kruskal- } \\
\text { Wallis } \\
\text { test) }\end{array}$ \\
\hline $10 \%$ Propolis & $5 \mathrm{mms}$ & 1 & 9.75 & \multirow{4}{*}{$\begin{array}{l}0.002^{*} \\
\text { Significant }\end{array}$} \\
\hline $\begin{array}{l}100 \% \text { Morinda } \\
\text { citrifolia juice }\end{array}$ & $5.5 \mathrm{mms}$ & 0 & 11.75 & \\
\hline $\begin{array}{l}2 \% \\
\text { Chlorhexidine }\end{array}$ & $17 \mathrm{mms}$ & 16.25 & 18.5 & \\
\hline $\begin{array}{l}5 \% \text { Sodium } \\
\text { hypochlorite }\end{array}$ & $17 \mathrm{mms}$ & 14.5 & 18.5 & \\
\hline
\end{tabular}

Table 3: Zones of inhibition of $E$. feacalis in millimetres for the 3 clinical isolates and ATCC [29212] tested using disc diffusion method for Chlorhexidine

\begin{tabular}{|c|c|c|c|c|c|c|c|}
\hline \multirow{2}{*}{$\begin{array}{l}\text { Concen- } \\
\text { trations } \\
\text { of } \\
\text { Chlor- } \\
\text { hexidine }\end{array}$} & \multicolumn{3}{|c|}{ Clinical isolates } & \multirow{2}{*}{$\begin{array}{l}\text { ATCC } \\
29212 \\
\end{array}$} & \multirow[t]{2}{*}{$\begin{array}{l}\text { Median } \\
\text { zones of } \\
\text { inhibi-tion } \\
\text { for E. } \\
\text { Faecalis } \\
\text { (in } \mathrm{mms} \text { ) }\end{array}$} & \multirow[t]{2}{*}{$\begin{array}{l}\text { Spear- } \\
\text { men's } \\
\text { corre- } \\
\text { lation } \\
\text { coeffi- } \\
\text { cient }\end{array}$} & \multirow{2}{*}{$\begin{array}{l}p \text {-value } \\
\text { and } \\
\text { signi- } \\
\text { ficance }\end{array}$} \\
\hline & 8 & 11 & 10 & & & & \\
\hline $2 \%$ & $\begin{array}{l}17 \\
\mathrm{~mm}\end{array}$ & $\begin{array}{l}15 \\
\mathrm{~mm}\end{array}$ & $\begin{array}{l}17 \\
\mathrm{~mm}\end{array}$ & $20 \mathrm{~mm}$ & $17 \mathrm{~mm}$ & & \\
\hline $1 \%$ & $\begin{array}{l}16 \\
\mathrm{~mm}\end{array}$ & $\begin{array}{l}12 \\
\mathrm{~mm}\end{array}$ & $\begin{array}{l}17 \\
\mathrm{~mm}\end{array}$ & $17 \mathrm{~mm}$ & $16.5 \mathrm{~mm}$ & & \\
\hline $0.5 \%$ & $\begin{array}{l}14 \\
\mathrm{~mm}\end{array}$ & $\begin{array}{l}18 \\
\mathrm{~mm}\end{array}$ & $\begin{array}{l}16 \\
\mathrm{~mm}\end{array}$ & $15 \mathrm{~mm}$ & $15.5 \mathrm{~mm}$ & 0.49 & 0.05 \\
\hline $0.2 \%$ & $\begin{array}{l}15 \\
\mathrm{~mm}\end{array}$ & $\begin{array}{l}15 \\
\mathrm{~mm}\end{array}$ & $\begin{array}{l}16 \\
\mathrm{~mm}\end{array}$ & $16 \mathrm{~mm}$ & $15.5 \mathrm{~mm}$ & & $\begin{array}{l}\text { Signi- } \\
\text { ficant }\end{array}$ \\
\hline
\end{tabular}

Inhibition was absent for $2.5 \%$ propolis and a positive association between the increasing concentrations and zones of inhibition for E. Faecalis, indicating a doseresponse relation, which was seen for all four agents. $10 \%$ propolis had a highest zone of inhibition for $E$. Faecalis and is hence the most efficient one (Graph 2-Box plot).

There was no inhibition for $0.75 \%$ and $1.5 \%$ Morinda citrifolia juice. $100 \%$ had the highest zone of inhibition and is hence the most efficient one (Graph 3-Box plot).

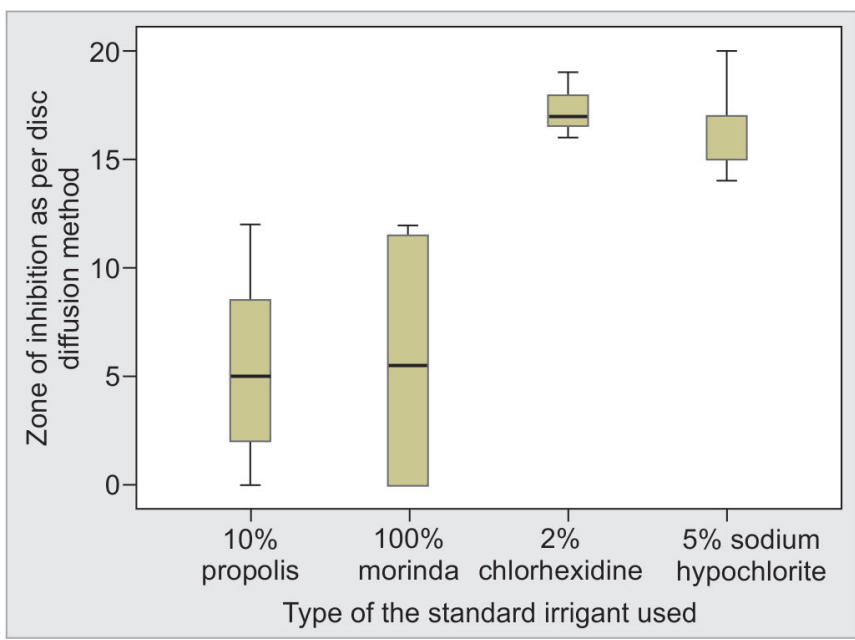

Graph 1: Comparison of different reagents against E. faecalis demonstrating zones of inhibition
Table 2: Zones of inhibition for E. faecalis in millimeters for the three clinical isolates and ATCC (29212) tested using disc diffusion method for sodium hypochlorite.

\begin{tabular}{|c|c|c|c|c|c|c|c|}
\hline \multirow[t]{2}{*}{$\begin{array}{l}\text { Concen- } \\
\text { trations } \\
\text { of } \\
\text { sodium } \\
\text { hypo- } \\
\text { chlorite }\end{array}$} & \multicolumn{3}{|c|}{ Clinical isolates } & \multirow{2}{*}{$\begin{array}{l}\text { ATCC } \\
29212 \\
\end{array}$} & \multirow[t]{2}{*}{$\begin{array}{l}\text { Median } \\
\text { zones of } \\
\text { inhibition } \\
\text { for } E \text {. } \\
\text { aecalis } \\
\text { (in } \mathrm{mms} \text { ) }\end{array}$} & \multirow[t]{2}{*}{$\begin{array}{l}\text { Spear- } \\
\text { men's } \\
\text { corre- } \\
\text { lation } \\
\text { coeffi- } \\
\text { cient }\end{array}$} & \multirow[t]{2}{*}{$\begin{array}{l}p \text {-value } \\
\text { and } \\
\text { signi- } \\
\text { ficance }\end{array}$} \\
\hline & 8 & 11 & 10 & & & & \\
\hline $5 \%$ & $\begin{array}{l}16 \\
\mathrm{~mm}\end{array}$ & $\begin{array}{l}17 \\
\mathrm{~mm}\end{array}$ & $\begin{array}{l}17 \\
\mathrm{~mm}\end{array}$ & $\begin{array}{l}19 \\
\mathrm{~mm}\end{array}$ & $17 \mathrm{~mm}$ & & \\
\hline $3 \%$ & $\begin{array}{l}14 \\
\mathrm{~mm}\end{array}$ & $\begin{array}{l}20 \\
\mathrm{~mm}\end{array}$ & $\begin{array}{l}14 \\
\mathrm{~mm}\end{array}$ & $\begin{array}{l}16 \\
\mathrm{~mm}\end{array}$ & $16 \mathrm{~mm}$ & & \\
\hline $2.5 \%$ & $\begin{array}{l}15 \\
\mathrm{~mm}\end{array}$ & $\begin{array}{l}15 \\
\mathrm{~mm}\end{array}$ & $\begin{array}{l}14 \\
\mathrm{~mm}\end{array}$ & $\begin{array}{l}14 \\
\mathrm{~mm}\end{array}$ & $14.5 \mathrm{~mm}$ & 0.74 & 0.001 \\
\hline $0.5 \%$ & $\begin{array}{l}14 \\
\mathrm{Mm}\end{array}$ & $\begin{array}{l}14 \\
\mathrm{~mm}\end{array}$ & $\begin{array}{l}11 \\
\mathrm{~mm}\end{array}$ & $\begin{array}{l}14 \\
\mathrm{~mm}\end{array}$ & $14 \mathrm{~mm}$ & & $\begin{array}{l}\text { Signi- } \\
\text { ficant }\end{array}$ \\
\hline
\end{tabular}

Table 4: Zones of inhibition for Candida Albicans in millimetres comparing the four standard concentration of test agents

\begin{tabular}{lllll}
\hline & $\begin{array}{l}\text { Median } \\
\text { zoneof } \\
\text { inhibition }\end{array}$ & & & \\
$\begin{array}{l}\text { Agent andthe } \\
\text { ftandard } \\
\text { Concentration }\end{array}$ & C Albicans & $\begin{array}{l}\text { First } \\
\text { Quartile }\end{array}$ & $\begin{array}{l}\text { Third } \\
\text { Quartile }\end{array}$ & $\begin{array}{l}p \text {-value } \\
\text { and signi- } \\
\text { ficance }\end{array}$ \\
\hline $\begin{array}{l}10 \% \text { Propolis } \\
100 \% \text { Morinda }\end{array}$ & 3.5 & 3 & 5 & \\
$\begin{array}{l}\text { Citrifolia juice. } \\
2 \% \text { Chlorhexidine }\end{array}$ & 21.5 & 1.25 & 2 & \\
$\begin{array}{l}5 \% \text { Sodium } \\
\text { Hypochlorite }\end{array}$ & 26 & 20.25 & 22.75 & $\begin{array}{l}<0.001, \\
\text { Significant } \\
\text { (Kruskal- } \\
\text { Wallis } \\
\text { test) }\end{array}$ \\
\hline
\end{tabular}

Five percent hypo and $2 \%$ chlorhexidine had the highest zone of inhibition for $E$. Faecalis and hence the most efficient ones (Tables 2 and 3).

Comparison of reagents against $C$. albicans showed a significant variation between zones of inhibition (Table 4). Among individual groups, 10\% Propolis had the least zone of inhibition. Morinda citrifolia juice had significantly better zones of inhibition compared to Propolis, whereas compared to $2 \%$ chlorhexidine and $5 \%$ hypo it had significantly lesser inhibition.

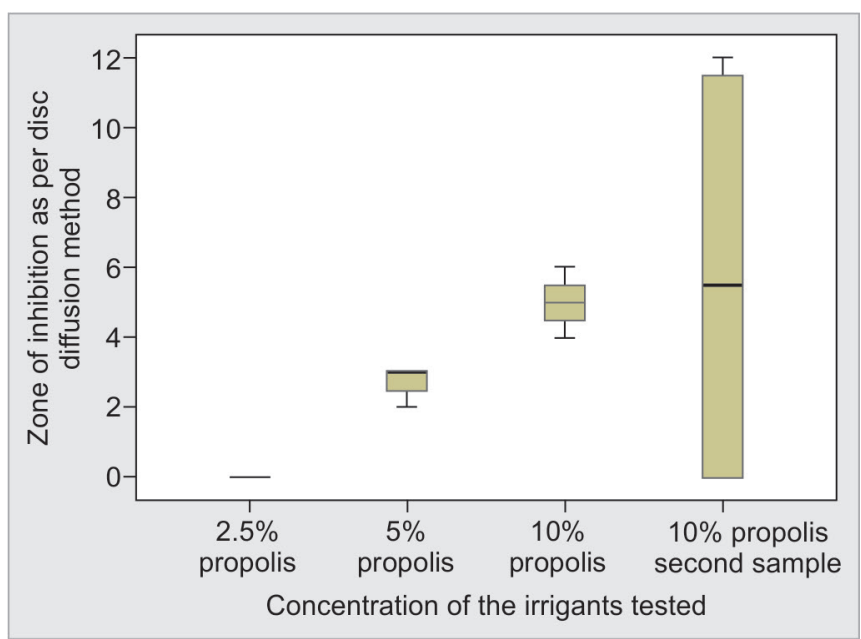

Graph 2: Zones of inhibition for various concentration gradients of propolis 
Table 5: Zones of inhibition for Candida albicans in millimetres for the 3 clinical isolates and ATCC [90028] tested using disc diffusion method for Propolis

\begin{tabular}{|c|c|c|c|c|c|c|c|}
\hline \multirow{3}{*}{$\begin{array}{l}\text { Concen- } \\
\text { trations } \\
\text { of } \\
\text { Propolis }\end{array}$} & \multirow{2}{*}{\multicolumn{3}{|c|}{ Clinical isolates }} & \multirow{3}{*}{$\begin{array}{l}\text { ATCC } \\
90028 \\
\end{array}$} & \multirow{3}{*}{$\begin{array}{l}\text { Median } \\
\text { zones of } \\
\text { inhibi- } \\
\text { tion for C } \\
\text { albicans } \\
\text { (in } \mathrm{mms} \text { ) }\end{array}$} & \multirow{3}{*}{$\begin{array}{l}\text { Spear- } \\
\text { men's } \\
\text { corre- } \\
\text { lation } \\
\text { coeffi- } \\
\text { cient }\end{array}$} & \multirow[t]{3}{*}{$\begin{array}{l}p \text { value } \\
\text { and } \\
\text { signi- } \\
\text { ficance }\end{array}$} \\
\hline & & & & & & & \\
\hline & 8 & 11 & 10 & & & & \\
\hline $10 \%$ & $5 \mathrm{~mm}$ & $3 \mathrm{~mm}$ & $3 \mathrm{~mm}$ & $5 \mathrm{~mm}$ & $4 \mathrm{~mm}$ & \multirow{4}{*}{0.874} & \multirow{4}{*}{$\begin{array}{l}<0.001 \\
\text { Signi- } \\
\text { ficant }\end{array}$} \\
\hline $10 \%$ & $5 \mathrm{~mm}$ & $4 \mathrm{~mm}$ & $3 \mathrm{~mm}$ & $3 \mathrm{~mm}$ & $3.5 \mathrm{~mm}$ & & \\
\hline $5 \%$ & $2 \mathrm{~mm}$ & $2 \mathrm{~mm}$ & $2 \mathrm{~mm}$ & $3 \mathrm{~mm}$ & $2 \mathrm{~mm}$ & & \\
\hline $2.5 \%$ & $0 \mathrm{~mm}$ & $0 \mathrm{~mm}$ & $0 \mathrm{~mm}$ & $0 \mathrm{~mm}$ & $0 \mathrm{~mm}$ & & \\
\hline
\end{tabular}

Table 7: Zones of inhibition for E. faecalis in millimetres comparing the four standard concentration of test agents (well diffusion method)

\begin{tabular}{|c|c|c|c|c|}
\hline $\begin{array}{l}\text { Agent andthe } \\
\text { standard } \\
\text { Concentration }\end{array}$ & $\begin{array}{l}\text { Median } \\
\text { zones of } \\
\text { inhibition for } \\
\text { E. Faecalis }\end{array}$ & $\begin{array}{l}\text { First } \\
\text { quartile }\end{array}$ & $\begin{array}{l}\text { Third } \\
\text { quartile }\end{array}$ & $\begin{array}{l}p \text {-value } \\
\text { and signi- } \\
\text { ficance }\end{array}$ \\
\hline $10 \%$ Propolis & 13 & 12.25 & 13.75 & \multirow[b]{3}{*}{$\begin{array}{l}<0.005, \\
\text { Significant } \\
\text { (Kruskal } \\
\text { Wallis } \\
\text { test) }\end{array}$} \\
\hline $\begin{array}{l}100 \% \text { Morinda } \\
\text { citrifolia juice }\end{array}$ & 4.5 & 4 & 5 & \\
\hline $\begin{array}{l}2 \% \\
\text { Chlorhexidine } \\
5 \% \text { Sodium } \\
\text { Hypochlorite }\end{array}$ & 21.5 & 18.75 & 22 & \\
\hline
\end{tabular}

We found a positive correlation among the increasing Propolis concentrations and zones of inhibition for C. albicans. 10\% Propolis had the highest zone of inhibition for Candida and is hence the most effective one (Table 5).

There was no inhibition for $0.75 \%$ and $1.5 \%$ concentration of Morinda citrifolia and a positive relation between the increasing concentrations and zone of inhibition. 100\% Morinda citrifolia juice had the highest zone of inhibition and is hence the most effective one (Table 6).

There was a positive but nonsignificant relation between the increasing concentrations and zone of

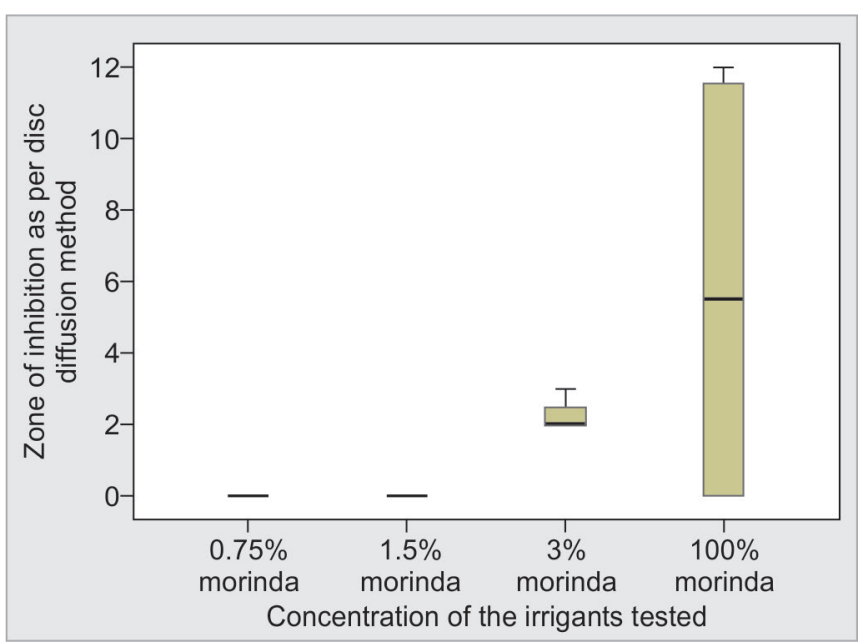

Graph 3: Zones of inhibition for different concentrations of Morinda citrifolia
Table 6: Zones of inhibition for Candida albicans in millimetres for the 3 clinical isolates and ATCC [90028] tested using disc diffusion method for morinda citrifolia juice.

\begin{tabular}{|c|c|c|c|c|c|c|c|}
\hline \multirow[t]{2}{*}{$\begin{array}{l}\text { Concen- } \\
\text { trations } \\
\text { of } \\
\text { Morinda } \\
\text { Citrifolia } \\
\text { juice }\end{array}$} & \multicolumn{3}{|c|}{ Clinical isolates } & \multirow{2}{*}{$\begin{array}{l}\text { ATCC } \\
90028 \\
\end{array}$} & \multirow[t]{2}{*}{$\begin{array}{l}\text { Median } \\
\text { zones of } \\
\text { inhibi- } \\
\text { tion for C } \\
\text { albicans } \\
\text { (in } \mathrm{mms} \text { ) }\end{array}$} & \multirow[t]{2}{*}{$\begin{array}{l}\text { Spear- } \\
\text { men's } \\
\text { correla- } \\
\text { tion } \\
\text { coeffi- } \\
\text { cient }\end{array}$} & \multirow{2}{*}{$\begin{array}{l}p \text {-value } \\
\text { and } \\
\text { signi- } \\
\text { ficance }\end{array}$} \\
\hline & 8 & 11 & 10 & & & & \\
\hline $100 \%$ & $2 \mathrm{~mm}$ & $1 \mathrm{~mm}$ & $2 \mathrm{~mm}$ & $2 \mathrm{~mm}$ & $2 \mathrm{~mm}$ & \multirow{4}{*}{0.8} & \multirow{4}{*}{$\begin{array}{l}<0.001 \\
\text { Signi- } \\
\text { ficant }\end{array}$} \\
\hline $3 \%$ & $2 \mathrm{~mm}$ & $2 \mathrm{~mm}$ & $2 \mathrm{~mm}$ & $3 \mathrm{~mm}$ & $2 \mathrm{~mm}$ & & \\
\hline $1.5 \%$ & $0 \mathrm{~mm}$ & $0 \mathrm{~mm}$ & $0 \mathrm{~mm}$ & $0 \mathrm{~mm}$ & $0 \mathrm{~mm}$ & & \\
\hline $0.75 \%$ & $0 \mathrm{~mm}$ & $0 \mathrm{~mm}$ & $0 \mathrm{~mm}$ & $0 \mathrm{~mm}$ & $0 \mathrm{~mm}$ & & \\
\hline
\end{tabular}

Table 8: Well diffusion results for single sample of all the concentrations of all the four test agents for ATCC [90028] sample of Candida albicans

\begin{tabular}{lll}
\hline Agent and concentration & $\begin{array}{l}\text { Zone of inhibition by disc } \\
\text { diffusion }\end{array}$ \\
\hline Propolis & $10 \%$ & $5 \mathrm{~mm}$ \\
& $5 \%$ & $3 \mathrm{~mm}$ \\
Morinda & $2.5 \%$ & 0 \\
Citrifolia juice & $3 \%$ & $1 \mathrm{~mm}$ \\
& $1.5 \%$ & $1 \mathrm{~mm}$ \\
Sodium & $0.75 \%$ & $1 \mathrm{~mm}$ \\
hypochlorite & $3 \%$ & $20 \mathrm{~mm}$ \\
& $2.5 \%$ & $22 \mathrm{~mm}$ \\
Chlorhexidine & $0.5 \%$ & $18 \mathrm{~mm}$ \\
& $1 \%$ & $26 \mathrm{~mm}$ \\
& $0.5 \%$ & $21 \mathrm{~mm}$ \\
& $0.2 \%$ & $17 \mathrm{~mm}$ \\
\hline
\end{tabular}

inhibition C. albicans. There were similar zones of inhibition for $5 \%, 3 \%$ and $0.5 \%$ concentrations. Even the lowest concentration of $0.5 \%$ showed an adequate zone of inhibition (Graph 4-Box plot).

Two percent chlorhexidine had the highest zone of inhibition for $C$. albicans and is hence the most effective one (Graph 5-Box plot).

There was no significant difference between $2 \%$ chlorhexidine and 5\% sodium hypochlorite's zone of

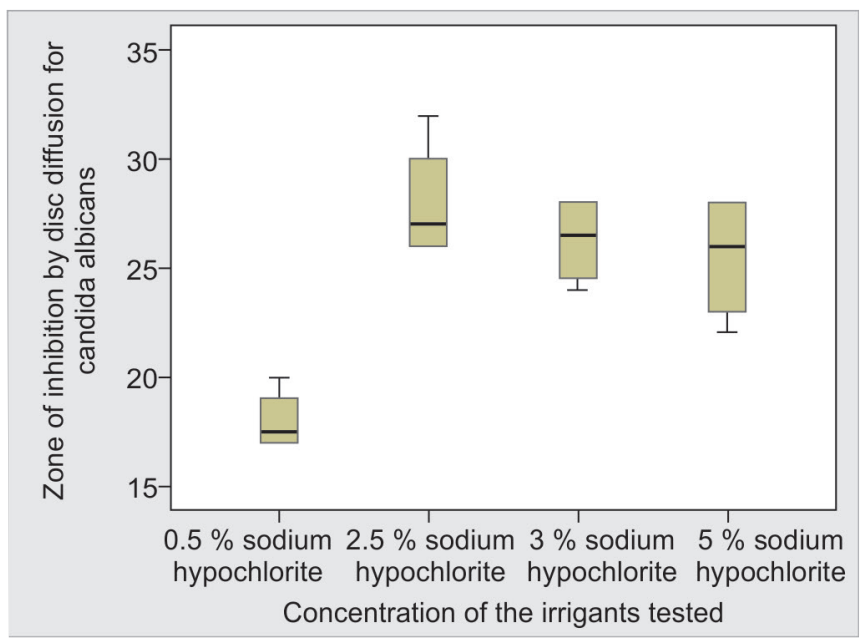

Graph 4: Zones of inhibition for Candida albicans against different concentration gradients of Sodium hypochlorite 


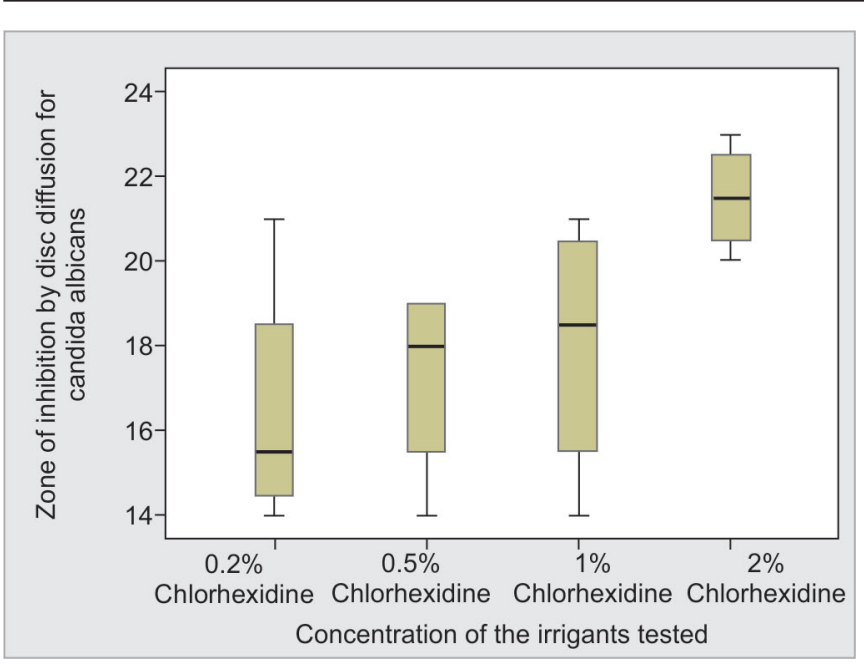

Graph 5: Zones of inhibition for Candida albicans against different concentrations of Chlorhexidine

inhibitions for E. faecalis tested by well diffusion method (Table 7).

Zone of inhibitions for C. albicans revealed that $1 \%$ chlorhexidine had the highest value followed by $3 \%$ sodium hypochlorite and 10\% Propolis (Table 8).

Zones of inhibition for Propolis were comparatively higher than Morinda citrifolia juice against E. faecalis, whereas the later agent showed better zones of inhibition than the former against $C$. albicans.

\section{DISCUSSION}

Persistent microorganisms like E. faecalis, C. albicans in root canals even after therapy cause failure of treatment. Therefore, adequate treatment strategies must include conventional intracanal irrigating medicaments like sodium hypochlorite and chlorhexidine and also newer herbal products like propolos and Morinda citrifolia fruit juice. ${ }^{1-3}$

Flavonoids like galangin and pinocembrin and phenolic acids or their esters in propolis contribute to the antimicrobial activity. ${ }^{8}$ Marcucci et al. showed the effective antifungal and antibacterial activity of $10 \%$ propolis. ${ }^{9}$ Similarly, Shveta et al. found $30 \%$ solution of Propolis was effectual against E. faecalis and C. albicans, after both 48 hours and 10 days of application. ${ }^{10}$

Tanins present in Morinda citrifolia contributes to its antimicrobial action owing to their toxicity that causes the destruction of bacteria and fungi, the other factor being it's high $\mathrm{pH}(3.5){ }^{11}$

The comparative study revealed a significant variation among zones of inhibition of all the four tested agents. The zones of inhibition for sodium hypochlorite $(5 \%)$ was comparatively higher than chlorhexidine ( $2 \%)$ but statistically insignificant, similar to the findings of Luddin and Ahmed. ${ }^{12}$ Both herbal agents had significantly lesser zones of inhibition compared to conventional ones. The solvent used for propolis extraction (ethanol, chloroform, methanol or propylene glycol) influences its antimicrobial action. The stage of ripeness and processing mechanism of Morinda citrifolia juice are supposed to be reasons for lesser antimicrobial activity. 2,3,13,14

There was no statistically significant difference between Propolis (10\%) and Morinda citrifolia juice (100\%) against $E$. faecalis, similar to the findings of Kandaswamy and Venkateshbabu ${ }^{15}$ and a significant difference against C. albicans, with Morinda citrifolia juice showing better zones of inhibition than propolis, similar to Carbajal Mejia findings. ${ }^{16}$

Jainkittivong et al. found the antifungal effect of Morinda citrifolia fruit extract on C. albicans which varied with concentration and contact time. ${ }^{17}$

Propolis in its different concentrations, when tested against $C$. albicans, showed larger zones of inhibitions at higher concentration (10\%). At lower concentrations, flavonoids present in the propolis might get further dissolved and be ineffective. This is similar to findings of Marcucci et al. who showed effective antifungal and antibacterial activity of $10 \%$ Propolis. ${ }^{9}$

Morinda citrifolia juice in its different concentrations, when tested against $C$. albicans, showed larger zones of inhibitions at higher concentration (100\%). There was no inhibition for $(0.75 \%, 1.5 \%)$. At concentration ( $3 \%)$, some antimicrobial effectiveness was seen. Our findings are similar to Wang et al. ${ }^{11}$

Hypo in various concentration against $C$. albicans demonstrated larger zones of inhibitions at higher concentration $(5 \%)$, though it was not statistically significant. The efficacy of hypo at a higher concentration on both microorganisms may be due to the concentration rise is directly related to the antimicrobial efficiency and tissue dissolution capacity. ${ }^{18}$

Chlorhexidine in its various concentrations, when tested against $C$. albicans, revealed larger zones of inhibitions at higher concentration $(2 \%)$, similar to findings of Estrella et al. ${ }^{19}$

We used well diffusion method to have more confirmatory and validated data and found results of higher zones of inhibition for hypo and Chlorhexidine than propolis and morinda citrifolia juice were in accordance with the disc diffusion method, without significant difference.

Further research must be concentrated to find out the antimicrobial effectiveness for propolis and morinda citrifolia juice to limit the side effects of routinely used intracanal irrigants like chlorhexidine and sodium hypochlorite.

\section{Limitations}

With three clinical isolates and one standard strain, the sample size available was four samples per group. Hence a larger study with a higher sample size may be needed to establish the significance of these findings further. 


\section{CONCLUSION}

We observed that sodium hypochlorite, chlorhexidine, Propolis, and Morinda citrifolia juice have an antimicrobial effect on all the microorganisms tested, with conventional agents, sodium hypochlorite, chlorhexidine; more efficient than herbal agents Propolis and Morinda citrifolia juice.

All the four irrigants showed their increased antimicrobial efficacy with increasing concentrations.

Hypo was more effectual than chlorhexidine against both the microorganisms.

\section{REFERENCES}

1. Mohammadi Z, Abott PV. The properties and applications of Chlorhexidine in endodontics. Int Endod J 2009;42 (4): 288- 302.

2. Arslan S, Ozbilge H, Kaya EG, Er O. In vitro antimicrobial activity of propolis, BioPure MTAD, sodium hypochlorite, and chlorhexidine on Enterococcus faecalis and Candida albicans. Saudi medical journal. 2011;32(5):479-483.

3. Ramani N, Mathew S. Comparative evaluation of antimicrobial efficacy of Chlorhexidine digluconate and Propolis when used as intracanal medicament. JIOH 2012; 4 (2):17-23.

4. Radeva E, Indjov B, Vacheva R. In vitro study of the effectiveness of intracanal irrigants on candida albicans. J of IMAB 2007; 13:3-7.

5. Ashraf H, Samiee M, Eslami G, Ghodse Hosseini MR. Presence of Candida Albicans in Root Canal System of Teeth Requiring Endodontic Retreatment with and without Periapical Lesions. Iranian Endodontic Journal. 2007;2(1): 24-28.

6. Pujar M, Patil C, Kadam A. Comparison of antimicrobial efficacy of triphala, (GTP) green tea polyphenols and 3\% of sodium hypochlorite on Enterococcus faecalis biofilms formed on tooth substrate: in vitro. JIOH 2011;3 (2):23-29.

7. Pujar M, Makandar S. Herbal usage in endodontics-A review. IJCD 2011;2 (1):34- 37.
8. Viuda-Martos M, Ruiz-Navajas Y, Fernandez-Lopez J, PerezAlvarez JA. Functional properties of honey, propolis and royal jelly. Journal of food science 2008;73:117-124.

9. Miguel MG, Antunes MD. Is propolis safe as an alternative medicine? J Pharm Bioall Sci 2011;3:479-495.

10. Shveta G, Kundabala M, Shashi RA, Vasudev B. A comparative evaluation of the antibacterial efficacy of propolis, 3.0\% sodium hypochlorite and $0.2 \%$ chlorhexidine gluconate against enterococcus faecalis-An in vitro study. Endodontology. 2007;19(2):31-38

11. Wang MY, West BJ, Jensen CJ, Nowicki D, Su C, Palu AK, Anderson G. Morinda citrifolia (Noni): a literature review and recent advances in Noni research. Acta Pharmacologica Sinica. 2002 Dec 1;23(12):1127-1141.

12. Luddin N, Ahmed HM. The antibacterial activity of sodium hypochlorite and chlorhexidine against Enterococcus faecalis: A review on agar diffusion and direct contact methods. J Conserv Dent 2013;16:9-16.

13. Kustarci A, Oktay E, Kılıç A, Özan Ü, Altunba D. Evaluation of antimicrobial efficacy of sodium hypochlorite, propolis, octenidine dihydrochloride and chlorhexidine on microorganisms. Cumhuriyet Dental Journal. 2011 Sep 22;14(3):183-190.

14. Al-Qathami H, Al-Madi E. Comparison of sodium hypochlorite, propolis and saline as root canal irrigants: A pilot study. Saudi Dent J. 2003 May;15(2):100-103.

15. Kandaswamy D, Venkateshbabu N. Root canal irrigants. J Conserv Dent 2010;13:256-264.

16. Carbajal Mejia JB. Antimicrobial effects of calcium hydroxide, chlorhexidine, and propolis on enterococcus faecalis and candida albicans. J Investig Clin Dent 2014;5:194-200.

17. Jainkittivong A, Butsarakamruha T, Langlais RP. Antifungal activity of Morinda citrifolia fruit extract against Candida albicans. Oral Surg Oral Med Oral Pathol Oral Radiol Endod. 2009 Sep;108(3):394-308.

18. Mohammadi Z. Sodium hypochlorite in endodontics. Int Dent J. 2008 Dec;58(6):329-41.

19. Estrela C, Estrela CR, Barbin EL, Spanó JC, Marchesan MA, Pécora JD. Mechanism of action of sodium hypochlorite. Brazilian dental journal. 2002;13(2):113-117. 